Univerzitet u Beogradu
Poljoprivredni fakultet
Institut za poljoprivrednu tehniku
Naučni časopis
POLJOPRIVREDNA TEHNIKA
Godina XLIII
Broj 2, 2018.
Strane: $11-16$

\title{
MODELING A STRATEGIC TOP MANAGEMENT IN THE IMPORTANCE OF THE MANAGEMENT OF THE FINANCE COMPANIES ESTABLISHED FOR THE ESTABLISHMENT OF FER VALUE
}

\author{
Slobodan Popović* ${ }^{1}$ \\ ${ }^{I}$ Faculty of Economics and Engineering Management, Cvećarska 2, Novi Sad, Srbia
}

\begin{abstract}
Modeling using management modes through the application of strategic management presupposes a modern approach that requires the company's adaptability to the environment, primarily the immediate surroundings of the enterprise itself. The actions undertaken by the top management should be brought in order to maximize the profit. In this paper, the authors give an overview of a possible model that assumes the following essential elements: time, activity within the company, and achievement of the planned results. In addition, the author emphasizes the importance of periodic evaluation of managers, and in that sense, the assessment has been translated into interval 1-10 as a possible interval of assessments to be undertaken at regular and announced intervals.
\end{abstract}

Key words: management, strategic management, model.

\section{INTRODUCTION}

The modern way and approach to model behavior of the company presupposes changing important socio-economic [1], value [2], [3], [4] and other manifestations of enterprises that are visible in a very short time. The final activities are seen at the end of the business year in the company's books.

The goal of all top management activities should be to reduce the risk to the company's operations [5], [6], [7], [8]. This creates the conditions for proper corporate governance [9], which ultimately is subject to audit processes [10], especially in medium and large companies of a strategic interest in the development of economics [11], [12], [13]. Such an approach to strategic management has been seen especially in developed economies, which we see in numerous works such as [14], [15].

*Corresponding author: slobodan.popovic49@gmail.com 


\section{MATERIAL AND METHODS}

Theoretical approach to the study of companies in the decision-making of strategic decisions of enterprises with the great contribution of the author to his own vision of possible development and observation of companies in the Republic of Serbia was used. In the opinion of the author, this is a unique approach that corresponds to transitional countries, such as the Republic of Serbia.

In this paper, the author draws attention to: the period of time in which the activities of the company occur, the period of the event itself in the company and the results achieved by the company by that operation.

This paper primarily deals with the medium-sized enterprises in the Republic of Serbia in terms of financial management, it is important to observe the following common features:

$>$ High degree of interdependence between financial and investment decisions

$>$ To a large extent exposed to the risk factor

$>$ Involvement of foreign investors in strategic and operational management

$>$ More intensive impact of investment decisions on the survival, growth and development of the entities,

$>$ Different view of the target functions of the company, etc.

\section{RESULTS AND DISCUSSION}

Using the setting given in the materials and methods of work, the author has attempted to theoretically set up strategic models of enterprise management according to new or dynamic principles that would include several essential components. First of all, it's a time frame. This refers to the beginning and the end of a process that was carried out in the company.

Second is the process of doing business in the company.

The third is to obtain the results of the activities that are the subject of further analysis in the company.

The author's approach to the model is given in the form of a schematic representation presented in figure (Fig.1).

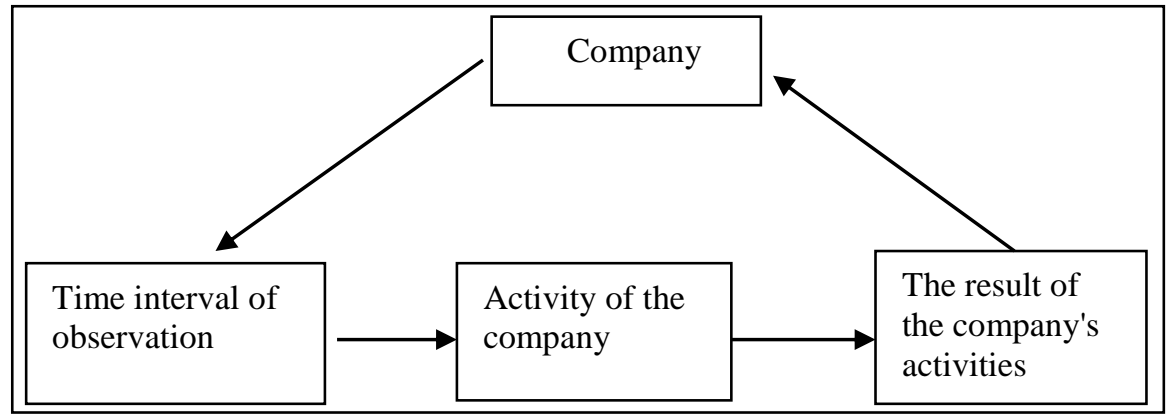

Figure 1. A model company that appreciates the strategic approach to governance in the Republic of Serbia 
Traditional strategic management is somewhat different from this model, which is best seen from the classical strategic management settings. Namely, he includes three areas of activity-strategic:

- Analysis which is needed to understand the events in the middle (especially in the market of their products and services)

- Choice relies on an analysis to create a vision that allows you to choose and consider real and alternative routes

- change which is the purpose of analysis and selection, if the application of the chosen direction does not lead to the desired position, business activity cannot be assessed positively and conditioned by strategic changes.

The importance of strategic management for managing the company's finance by top management.

Strategic management falls into top management as it requires knowledge of the whole enterprise and relationships with the environment. Deciding on this domain has long-term implications for the company's progress and success. Strategic management includes an analysis of the overall effectiveness and efficiency of the company's operations.

The strategic management process involves three focuses on which the enterprise must pay attention:

1. Strategic analysis,

2. Strategic choice and

3. Strategic implementation.

In addition, accountability can be attributed to the performance of the top-manager, as he takes into account the reputation of the company on the market, the creditworthiness, the professional staff, the management of their own and borrowed funds, all for the purpose of transforming into the profit of the company that is in the focus of the top management setting.

The author gives possible features of a top-manager who is oriented to financial management in relation to the possible interval, which is possible to evaluate the work of the manager within the company or outside. The display itself is given in Table 1.

Table 1. Tabular overview of the desirable top-management properties in relation to the evaluation interval

\begin{tabular}{|c|l|c|}
\hline Serial number & Top management features & $\begin{array}{c}\text { Possible evaluation interval for top } \\
\text { management }\end{array}$ \\
\hline 1. & Creativity & $1-10$ \\
\hline 2. & Persistence & $1-10$ \\
\hline 3. & Exploring spirit & $1-10$ \\
\hline 4. & Initiative & $1-10$ \\
\hline 5. & Independence & $1-10$ \\
\hline 6. & Expert & $1-10$ \\
\hline 7. & Responsible & \\
\hline
\end{tabular}




\section{CONCLUSIONS}

This paper focuses on setting up a strategic management model that is fundamentally focused on improving financial management. Thus, the analysis is transferred to the study of activities related to the provision of sufficient volume of financial assets that could normally perform the business of the company in the given economic conditions. The goal is to maximize profits. Top management should create such a real management company where the relationship between the acquired and the necessary funds will be close to optimal for the estimated level of development of the company. Strategic management should be viewed much wider than simply set goals by top management. Accordingly, a large number of external environmental factors, chances and threats, realistic estimation of the company's own strengths and weaknesses should be included. The way that it is complemented is essentially a strategy other than goals that represent what they want to achieve.

The author points out that it is possible to notice several stages in the functioning of the top management strategy:

- Strategy formulation

- Implementation of the strategy

- Strategic control.

Based on the above it is possible to present the most important functions of financial management such as: financial planning, financial organization, and selection of financial personnel, financial management and financial control. What will specifically take top management remains on it because there is no making an ideal recommended decision that would be universally applicable in any company.

\section{REFERENCES}

[1] Popović., S., (2014), Socio-ekonomski faktori ograničenja razvoja agrara, Monografija, Feljton, Novi Sad.

[2] Popović, S., Novaković, S., Đuranović, D., Mijić, R., Grublješić, Ž., Aničić, J. \& Majstorović, A. (2017). Application of international accounting standard-16 in a public company with predominantly agricultural activities, Economic Research-Ekonomska Istraživanja, Vol. 30, No. 1, 1850-1864.

[3] Gritsenko O.I. and Skorba O.A., (2015), Internal business control of service quality costs: managerial aspect, Actual problems of economics, 3, pp. 365-373.

[4] Panchuk P., (2015), Harmonization of accounting and taxation accounting at reporting formation on income. Actual problems of economy, pp. 373-379.

[5] Popović S., (2015), Implementacija heterogenih rizika u radu interne revizije, Revizor, 69, str. 7-19. 
[6] Popović S., Majstorović A., Grublješić Ž., (2015), Valuation of facilities in use and application of international accounting standards. Actual problems of economy, p. 379-387.

[7] Popović, S., (2015), Implementacija heterogenih rizika u radu interne revizije, Revizor, No. 69, pp.7-19.

[8] Popović, S., (2015), Interna revizija kao pokretač finansijske analize u javnim preduzećima RS, Revizor, 72, str. 41-53.

[9] Cantino, V. (2010), Korporativno uptravjanje, merenje performansi i normativna usaglašenost sistema internih kontrola, Data Status, Beograd, p. 17.

[10] Majstorović A. and Popović S. (2015), Revizija poslovanja poljoprivrednog preduzeća, Računovodstvo, 1, 77-85.

[11] Bromwich, M. (1990). The case for strategic management accounting: The role of accounting information for strategy in competitive markets. Accounting, Organizations, Society, 15(1-2), 27-46.

[12] Cinquini, L., \& Tenucci, A. (2010). Strategic management accounting and business strategy: A loose coupling? Journal of Accounting and Organizational Change, 6(2), 228-259.

[13] Cravens, K. S., \& Guilding, C. (2001). An empirical study of the application of strategic management accounting techniques. Advances in Management Accounting, 10, 95-124.

[14] Wooldridge, B. and Floyd, S.W. (1990), "The strategy process, middle management involvement and organizational performance", Strategic Management Journal, Vol.11, 231241.

[15] Zelbst, P., Green, K. W., Abshire, R. D. and Sower, V. E. (2010), "Relationships among market orientation, JIT, TQM, and agility", Industrial Management \& Data Systems, Vol. $110,637-658$.

\section{MODELIRANJE STRATEGIJSKOG TOP-MENADŽMENTA UZ UVAŽAVANJE UPRAVLJANJA FINANSIJAMA KOMPANIJE ZASNOVANIM NA UVOĐENJU FER VREDNOVANJA}

\section{Slobodan Popović ${ }^{1}$}

${ }^{1}$ Fakultet za ekonomiju i industrijski menadžment, Cvećarska 2, Novi Sad, Srbija

Sažetak: Modeliranje pomoću moedla upravljanja putem primene strategijskog menadžmenta pretpostavlja savremen pristup koji zahteva prilagodljivost kompanije okruženju, prvenstveno neposrednom koje okružuje samo preduzeće. Preduzete akcije od strane top menadžmenta treba da budu donešene sa ciljem maksimalizacije profita. $U$ ovom radu autori daju prikaz mogućeg modela koji pretpostavlja sledeće bitne elemente: vreme, aktivnost unutar kompanije i dostizanje zacrtanih rezultata. Osim toga autor ističe značaj periodičnog ocenjivanja menadžera i u tom smislu su ocenjivanje apostrofirali u interval 1-10 kao mogući interval ocene koji treba preduzimati u redovnim i najavljenim intervalima.

Ključne reči: upravljanje, strategijski menadžment, model. 
Prijavljen:

Submitted:

Ispravljen:

Revised:

Prihvaćen:

Accepted:

15.05.2018.

15.06.2018

20.06.2018. 